\title{
Post-Receptor Mechanisms Underlying Striatal Long-Term Depression
}

\author{
Paolo Calabresi,' Antonio Pisani, ${ }^{1}$ Nicola B. Mercuri, ${ }^{1}$ and Giorgio Bernardi ${ }^{\dagger, 2}$ \\ ${ }^{1}$ Clinica Neurologica, Dip. Sanitá, Universitá di Tor Vergata and ${ }^{2}$ RCCS, Clinica S. Lucia, 00173 Rome, Italy
}

\begin{abstract}
Extracellular and intracellular recordings were obtained from striatal neurons in a brain slice preparation in order to characterize the post-receptor mechanisms underlying striatal posttetanic long-term depression (LTD). Striatal LTD was blocked in neurons intracellularly recorded either with 1,2bis (o-aminophenoxy)-ethane- $N, N, N^{\prime}, N^{\prime}$-tetraacetic acid (BAPTA) or with EGTA, calcium $\left(\mathrm{Ca}^{2+}\right)$ chelators. Intracellular injection of QX-314, a lidocaine derivative that has been shown to block voltage-dependent sodium channels, abolished action potential discharge and blocked striatal LTD. However, under this condition, striatal LTD was restored when, immediately before the delivery of the tetanus, the cell was depolarized at a membrane potential ranging between $-\mathbf{3 0} \mathrm{mV}$ and $-\mathbf{2 0} \mathrm{mV}$ by injecting continuous positive current. Nifedipine (10 $\mu \mathrm{M})$, a blocker of voltage-dependent L-type $\mathrm{Ca}^{2+}$ channels, blocked striatal LTD. Nifedipine by itself altered neither cortically evoked EPSPs nor input resistance and firing properties of most of the recorded cells. Striatal LTD was also reduced or blocked by incubation of the slices in the presence of the following inhibitors of $\mathrm{Ca}^{2+}$. dependent protein kinases: staurosporine (10-50 nM), 1-(5isoquinolinesulfonyl)-2-methylpiperazine ( $\mathrm{H}-7 ; 10-50 \mu \mathrm{M})$, and calphostin $\mathrm{C}(1 \mu \mathrm{M})$. Our findings suggest that generation of striatal LTD requires a $\mathrm{Ca}^{2+}$ influx through voltage-dependent nifedipine-sensitive $\mathrm{Ca}^{2+}$ channels and a sufficient intracellular free $\mathrm{Ca}^{2+}$ concentration. Furthermore, this form of synaptic plasticity seems to involve the activation of $\mathrm{Ca}^{2+}$ dependent protein kinases. Different drugs, acting at receptor and/or post-receptor level, may affect this form of synaptic plasticity and might alter the formation of motor memory.
\end{abstract}

[Key words: calcium ions, long-term depression, motor memory, second messengers, striatum, synaptic plasticity]

A dominant concept of the classical neurobiology was that during the phylogenetic development of the CNS the higher behavioral functions such as mood, learning, and formation of motor memory were progressively located in the cerebral cortices (Hikosaka, 1991). This idea was supported by the discovery of different forms of synaptic plasticity in the cortical areas of

\footnotetext{
Received Nov. 4, 1993; revised Jan. 24, 1994; accepted Feb. 8, 1994

We thank G. Gattoni and M. Tolu for their excellent technical assistance. This study was supported by C.N.R. grants to P.C. (FATMA 'Stress') and to G.B. (Chimica Fine)

Correspondence should be addressed to Dr. Paolo Calabresi, Clinica Neurologica, Dip. Sanitá, Universitá di Roma Tor Vergata, Via O. Raimondo, 00173 Rome, Italy

Copyright (C) 1994 Society for Neuroscience $0270-6474 / 94 / 144871-11 \$ 05.00 / 0$
}

the brain (Bliss and Lomo, 1973; Artola and Singer, 1987; Hirsch and Crepel, 1990; Zalutsky and Nicoll, 1990; Kato, 1993). LTP of synaptic transmission in the hippocampus is the form of neural plasticity which has received much attention as a possible elementary basis for learning and memory (Lynch and Baudry, 1984; Teyler and DiScenna, 1984). Recent clinical and experimental studies on the function of the basal ganglia have provided evidence that this system is also fine tuned for behavioral selection and for the formation of motor memory (De I ong, 1990; Seitz et al., 1990; Hikosaka, 1991). Despite this recent evidence, the lack of a neuronal substrate for long-term synaptic changes in this system has weakened the concept of a prominent role of the basal ganglia in the memory processes. It has recently been reported that repetitive activation of corticostriatal glutamatergic fibers produces long-term depression (LTD) of excitatory synaptic transmission in the striatum recorded in vitro (Calabresi et al., 1992a,b; Lovinger et al., 1993; Walsh, 1993). Garcia-Munoz et al. (1992) observed long-term changes in the corticostriatal presynaptic afferents in vio. Corticostriatal glutamatergic fibers represent the major excitatory input to the striatum (Buchwald et al., 1973; Kitai et al., 1976; Spencer, 1976; Divac et al., 1977; Reubi and Cuenod, 1979). The striatal control of motor activity requires the participation of the dopaminergic nigrostriatal pathway (for reviews, see Groves, 1983; Graybiel, 1990). Coactivation of D1 and D2 dopamine receptors is necessary for both motor control (Robertson and Robertson, 1986, 1987), and generation of striatal LTD (Calabresi et al., 1992a). Generation of striatal LTD seems to involve also $\mathrm{Ca}^{2+}$ mobilization and changes in phosphatidylinositol (PI) turnover as suggested by the blockade of this form of synaptic plasticity by lithium (Calabresi et al., 1993) and by L-2-amino-3-phosphonopropionic acid (L-AP3) (Calabresi et al., 1992b), an antagonist of glutamate metabotropic receptors. Interestingly, both lithium and drugs acting on glutamate metabotropic receptors affect motor behavior (Branchey et al., 1973; Tyrer et al., 1980; Sacaan et al., 1992). All these findings, taken together, indicate that generation of striatal LTD, as well as the behavioral activation and the motor learning (Izquierdo, 1992; Svensson et al., 1992), involves both glutamatergic and dopamincrgic ncurotransmission. Stimulation of postsynaptic dopaminergic and glutamatergic receptors might alter the intracellular homeostasis and activate different second messenger systems. Although this hypothesis is attractive, it has not been investigated yet. We have characterized the role of $\mathrm{Ca}^{2}+$ ions in the generation of striatal LTD. We have also analyzed the role of $\mathrm{Ca}^{2+}$-dependent protein kinases in the formation of this phenomenon since second messenger pathways have been involved in synaptic plasticity and learning (for reviews, see Kuba and Kumamoto, 1990; Madison et al., 1991). 
Table 1. Characteristics of the recorded cells in different pharmacological conditions

\begin{tabular}{|c|c|c|c|c|c|c|}
\hline Drug & $\begin{array}{l}\text { EPSP } \\
\text { amplitude } \\
\text { before drug } \\
\text { application } \\
(\mathrm{mV})\end{array}$ & $\begin{array}{l}\text { EPSP } \\
\text { amplitude } \\
\text { during drug } \\
\text { application } \\
\text { (mV) }\end{array}$ & $\begin{array}{l}\text { RMP } \\
\text { before drug } \\
\text { application } \\
(\mathrm{mV})\end{array}$ & $\begin{array}{l}\text { RMP } \\
\text { during drug } \\
\text { application } \\
(\mathrm{mV})\end{array}$ & $\begin{array}{l}\text { Membrane } \\
\text { potential } \\
\text { during } \\
\text { tetanic } \\
\text { stimulation } \\
\text { without drug } \\
(\mathrm{mV})\end{array}$ & $\begin{array}{l}\text { Membrane } \\
\text { potcntial } \\
\text { during } \\
\text { tetanic } \\
\text { stimu- } \\
\text { lation } \\
\text { during } \\
\text { drug } \\
\text { appli- } \\
\text { cation } \\
\text { (mV) }\end{array}$ \\
\hline $\begin{array}{l}\text { BAPТA } \\
n=10\end{array}$ & $23 \pm 4^{b}$ & $22 \pm 4$ & $-85 \pm 6^{b}$ & $-84 \pm 7$ & $-58 \pm 6$ & $-58 \pm 6$ \\
\hline $\begin{array}{l}\text { EGTA } \\
n=8\end{array}$ & $22 \pm 3^{b}$ & $21 \pm 4$ & $-86 \pm 7^{b}$ & $-85 \pm 6$ & $-58 \pm 6$ & $-59 \pm 6$ \\
\hline $\begin{array}{l}\text { QX-314 } \\
n=8\end{array}$ & $23 \pm 4^{b}$ & $21 \pm 5$ & $-85 \pm 7^{b}$ & $-84 \pm 6$ & $-58 \pm 6$ & $-59 \pm 7$ \\
\hline $\begin{array}{l}\text { nifed. } \\
10 \mu \mathrm{M} \\
n=10\end{array}$ & $24 \pm 4$ & $23 \pm 4$ & $-86 \pm 7$ & $-86 \pm 7$ & $-58 \pm 6$ & $-59 \pm 6$ \\
\hline $\begin{array}{l}\omega \text {-Con. } \\
5 \mu \mathrm{M} \\
n=4\end{array}$ & $24 \pm 4$ & $4 \pm 2$ & $-85 \pm 6$ & $-86 \pm 6$ & $-58 \pm 6$ & - \\
\hline $\begin{array}{l}\mathrm{H}-7 \\
50 \mu \mathrm{M} \\
n=10\end{array}$ & $24 \pm 4$ & $23 \pm 4$ & $-84 \pm 7$ & $-85 \pm 6$ & $-58 \pm 6$ & $-59 \pm 7$ \\
\hline $\begin{array}{l}\text { Staur. } \\
50 \mu \mathrm{M} \\
n=9\end{array}$ & $22 \pm 4$ & $23 \pm 3$ & $-85 \pm 6$ & $-85 \pm 6$ & $-58 \pm 6$ & $-58 \pm 8$ \\
\hline $\begin{array}{l}\text { Calph. } \\
1 \mu \mathrm{M} \\
n=4\end{array}$ & $23 \pm 4$ & $22 \pm 5$ & $-86 \pm 6$ & $-85 \pm 7$ & $-58 \pm 6$ & $-58 \pm 8$ \\
\hline
\end{tabular}

a The mean membrane potential observed during tetanic stimulation (achieved between action potentials) in 20 experiments performed in control saline was considered as the potential reached during tetanic stimulation in the absence of drugs.

${ }^{b}$ In these experiments the drug was present in the recording electrode; for this reason the values measured immediately after the cell penetration were considered as control EPSP and control RMP (resting membrane potential).

\section{Materials and Methods}

Wistar rats were used for the experiments. Coronal slices $(200-300 \mu \mathrm{m})$ were prepared from tissue blocks of the brain with the use of a vibratome. These slices included the neostriatum and the neocortex. A single slice was transferred to a recording chamber $(0.5 \mathrm{ml}$ volume $)$ and submerged in a continuously flowing Krebs' solution $\left(35^{\circ} \mathrm{C}, 2-3 \mathrm{ml} / \mathrm{min}\right)$ gassed with a $95 \% \mathrm{O}_{2}, 5 \% \mathrm{CO}_{2}$ mixture. The composition of the solution was (in mM) $126 \mathrm{NaCl}_{2} 2.5 \mathrm{KCl}, 1.2 \mathrm{NaH}_{2} \mathrm{PO}_{4}, 1.2 \mathrm{MgCl}_{2}, 2.4 \mathrm{CaCl}_{2}$, 11 glucose, and $25 \mathrm{NaHCO}_{3}$. Intracellular recording electrodes were filled with $2 \mathrm{M} \mathrm{KCl} \mathrm{(30-60} \mathrm{M} \Omega$ ). In some intracellular experiments either $200 \mathrm{~mm}$ BAPTA or $500 \mathrm{~mm}$ EGTA were added to the solution of the intracellular pipette. In other experiments $50 \mathrm{~mm}$ QX-314 was added to the solution of the intracellular pipette.

Intracellular and extracellular potentials were recorded with the use of an Axoclamp-2A amplifier, displayed on an oscilloscope, and stored in a digital system. For afferent stimulation, bipolar electrodes were used. The stimulating electrode was located- either in cortical areas close to the recording electrode $(0.5-3 \mathrm{~mm})$ or in the white matter between the cortex and the striatum. As a conditioning tetanus, we used three trains ( $3 \mathrm{sec}$ duration, $100 \mathrm{~Hz}$ frequency, at $20 \mathrm{sec}$ intervals). The duration of each individual pulse was $0.01-0.03 \mathrm{msec}$. During the tetanic stimulation, the intensity was increased to suprathreshold levels in the intracellular experiments and to levels producing the maximal ampli- tude of the field potential in the extracellular experiments (approximately twice the test intensity). The field potential amplitude was defined as the average of the amplitude from the peak of the early positivity to the peak negativity, and the amplitude from the negativity to the peak late positivity (Alger and Teyler, 1976). Quantitative data on posttetanic modifications are expressed as a percentage of the controls, the latter representing the mean of responses recorded during a stable period (15-30 $\mathrm{min}$ ) before tetanic stimulation. Values given in the text and in the figures are means \pm SEM of changes in the respective cell populations. A paired $t$ test was used to compare the effect of tetanic stimulation in each experimental condition. The statistical analysis was performed by comparing the values of the EPSP amplitude measured before the tetanus with those observed $20 \mathrm{~min}$ after tetanic stimulations. Drugs were applied by dissolving them to the desired final concentration in saline and by switching the perfusion from the control saline. Nifedipine was dissolved in ethanol and protected from light before and during experiments. Control experiments were performed to rule out possible effects of this vehicle on the synaptic and intrinsic properties of the recorded neurons. The drugs studied on striatal LTD did not significantly (paired $t$ test) affect by themselves the EPSP amplitude, the resting membrane potential (RMP) and the amplitude of the membrane depolarization caused by the tetanic stimulation (see Table 1). Only $\omega$-conotoxin caused a significant $(p<0.005)$ reduction of EPSP amplitude without affecting RMP (Table 1). 


\section{Results}

Characteristics of striatal LTD

Intracellular and extracellular recordings were obtained from striatal neurons by utilizing a corticostriatal brain slice preparation (Calabresi et al., 1990, 1991). For synaptic stimulation bipolar electrodes were located either in the cortical areas close to the recording electrode or in the white matter between the cortex and the striatum. Previous evidence has shown that corticostriatal transmission is mediated by glutamate receptors (Herrling, 1985; Cherubini et al., 1988; Walsh et al., 1989; Calabresi et al., 1991; Jiang and North, 1991; Lovinger, 1991). Both intracellularly and extracellularly recorded synaptic potentials were blocked by 6-cyano-7-nitroquinoxaline-2,3-dione, an antagonist of AMPA-like glutamate receptors, but not by 2-amino-5-phosphonovalerate (APV), an antagonist of NMDAglutamate receptors (Calabresi et al., 1992c). In most of the intracellularly recorded neurons ( 22 out of 40 ), a rapid and persistent $(>2 \mathrm{hr} ; p<0.005)$ depression of the EPSPs was observed immediately after the conditioning tetanus (for the characteristics of the tetanus, see Materials and Methods). In the remaining cells, a short-term (1-3 min) posttetanic potentiation preceded the development of LID $(p<0.05)$. The graph in Figure 1 (solid squares) shows the time course of the LTD observed in the intracellular experiments in which posttetanic LTD was measured for at least $30 \mathrm{~min}$ in the absence of any pharmacological manipulation. In the other 20 cells in which LTD was induced, different pharmacological manipulations were performed either before or after the tetanus; for this reason data obtained from these neurons were not included in the graph shown in Figure 1. In none of the tested cells did the conditioning tetanus affect either the firing discharge, activated by direct depolarization, or other postsynaptic membrane properties such us membrane potential, input resistance, and current-voltage relationship. LTD of synaptic transmission was also detected by extracellular recordings. Under control condition, the posttetanic depression of the field potential decreased slightly within approximately $20 \mathrm{~min}$ and was then followed by a persistent depression ( $p<0.05$; see Fig. 5, solid squares).

\section{Blockade of LTD by $\mathrm{Ca}^{2+}$ chelators}

A rise in $\mathrm{Ca}^{2}$ ' concentration is the first intracellular postsynaptic event required for the generation of long-term changes of synaptic transmission in different neuronal types (Lynch et al., 1983; Sakurai, 1990; Brocher et al., 1992; Konnerth et al., 1992; Kato, 1993). In order to examine the role of postsynaptic $\mathrm{Ca}^{2+}$ concentration in striatal LTD, we injected striatal neurons with the $\mathrm{Ca}^{2+}$ chelators, BAPTA and EGTA, through low resistance (20$30 \mathrm{M} \Omega$ ) intracellular electrodes. These chelators rapidly bind intracellular free $\mathrm{Ca}^{2+}$. Cells were injected either with BAPTA (200 $\mathrm{mm}$ ) or with EGTA (500 $\mathrm{mm}$ ) for 20-30 min before the LTD inducing stimuli were applied. As shown in Figures 1 and 2 (open circles), striatal LTD was fully blocked by the injection of these $\mathrm{Ca}^{2+}$ chelators in the postsynaptic cell. No significant change of the EPSP amplitude was detected 20 min after tetanic stimulation in the experiments utilizing $\mathrm{Ca}^{2+}$ chelator-filled electrodes (paired $t$ test). To ensure that the tetanic stimulation of the corticostriatal pathway was capable of generating LTD, in some experiments we simultaneously recorded the extracellular field potentials from neighboring neurons and these showed a significant LTD (not shown). The sensitivity of striatal LTD
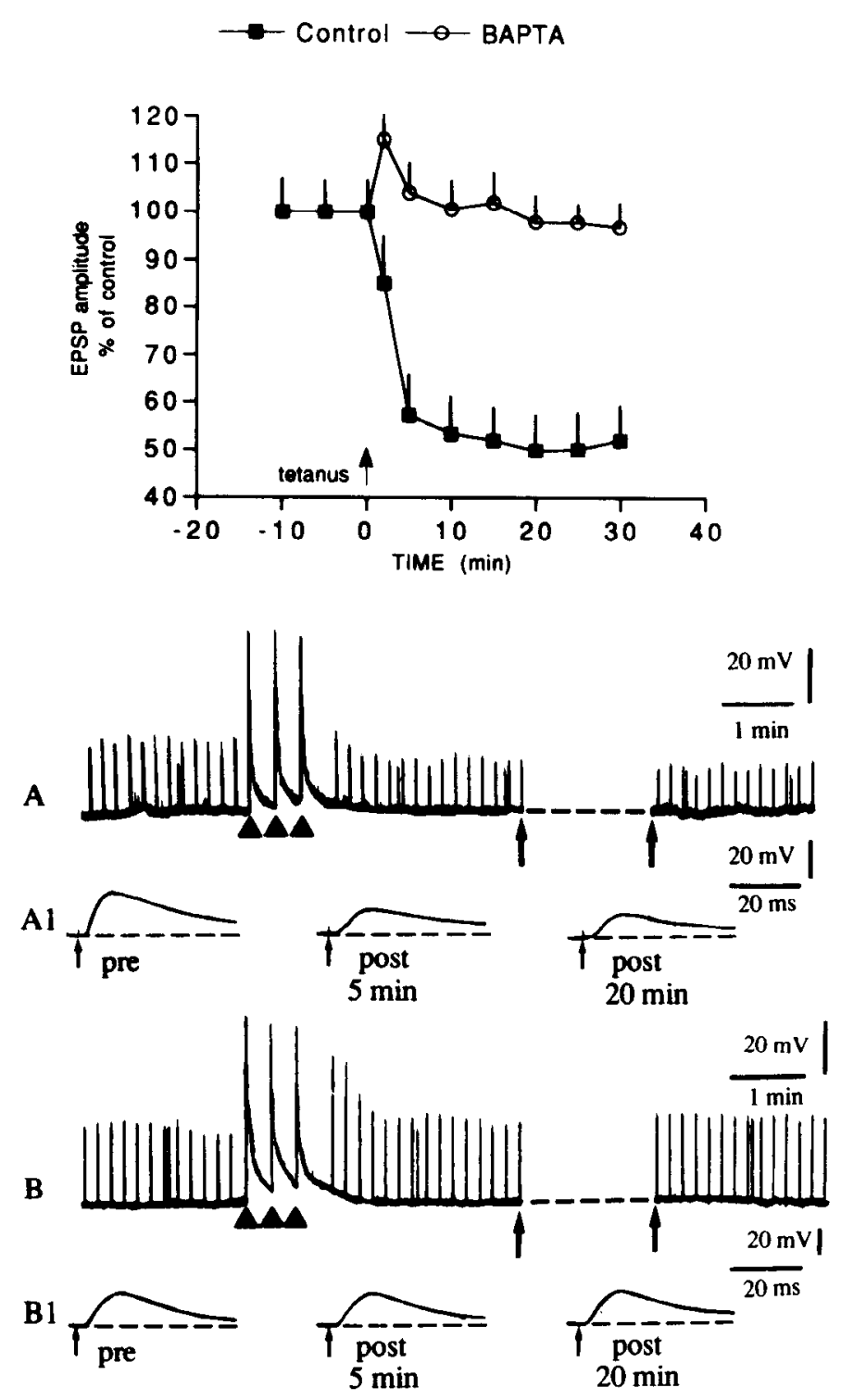

Figure 1. Tetanic stimulation of corticostriatal fibers induces LTD in control neurons, but not in BAPTA-filled cells. The graph in the upper part of the figure shows the effect of tetanic stimulation in striatal neurons under control condition $(n=20$, solid squares; the same control data are also shown in Figs. $2,5-8)$ and in BAPTA-filled cells $(n=10$, open circles). The lower part of the figure shows two single experiments obtained, respectively, from a control cell $(A, A I)$ and from a neuron filled with BAPTA $(B, B I) . A$, The trace shows the chart record of the membrane potential and of the EPSP amplitude (upward deflections) before and after tetanic stimulation in a control neuron (the tetanus is represented by three solid triangles). In this figure and in the following ones the dotted line between two arrows indicates a $15 \mathrm{~min}$ period of interruption of the trace. The resting membrane potential (RMP) was $-85 \mathrm{mV} . A 1$, In the same cell EPSPs are recorded at higher sweep speed, respectively, before (pre) and after tetanic stimulation (post). In this figure and in the following ones each trace is an average of at least four single sweeps. $B$, The chart record shows the effect of tetanic stimulation in a striatal neuron filled with BAPTA (RMP $=-83 \mathrm{mV}) . B 1$, In the same cell the EPSP amplitude is shown before (pre) and after the tetanus (post) at higher sweep speed. Note that the tetanic stimulation did not generate long-term changes of EPSP amplitude in the BAPTA-filled cell. 

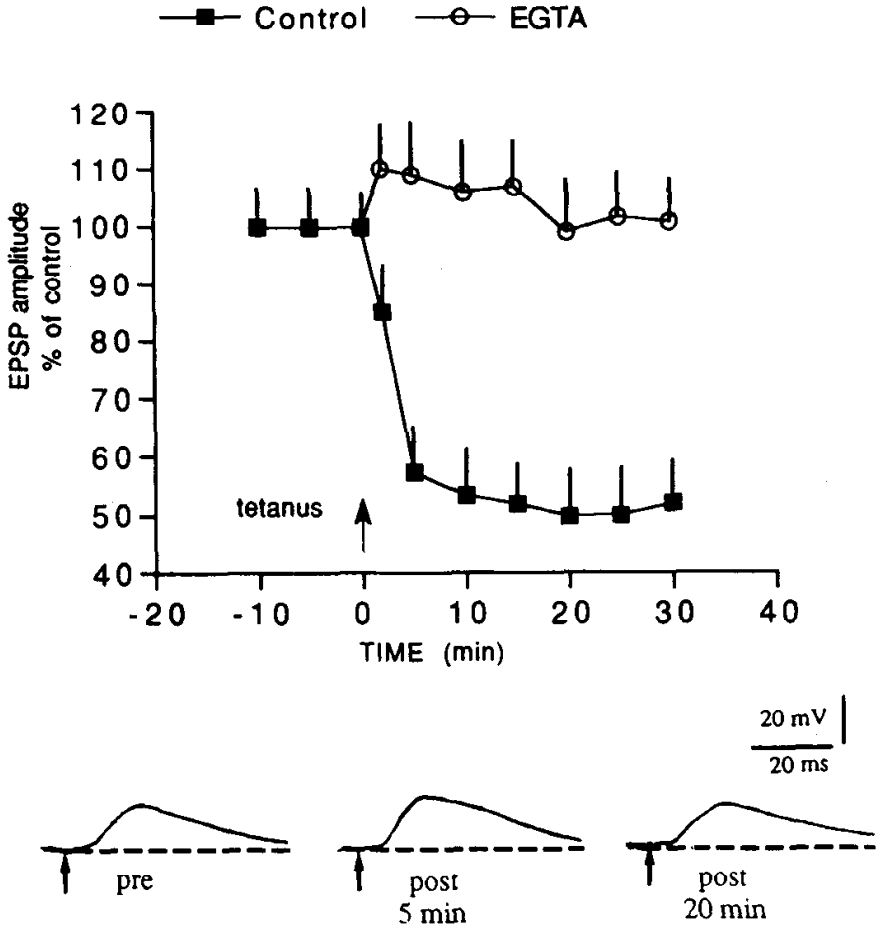

Figure 2. Blockade of LTD in EGTA-filled neurons. The graph shows LTD in control condition ( $n=20$, solid squares) and in neurons injected with 500 mM EGTA ( $n=8$, open circles). The traces shown in the lower part of the figure represent averages of EPSPs recorded by utilizing an EGTA-filled electrode before and after ( 5 and $20 \mathrm{~min})$ the tetanic stimulation (RMP $=-83 \mathrm{mV}$ ).

to intracellular BAPTA and EGTA demonstrates that intracellular free $\mathrm{Ca}^{2+}$ is required for this form of synaptic plasticity.

\section{$L T D$ in $Q X-314-$ filled neurons}

The induction of striatal LTD requires a tetanic stimulation which is able to cause a significant membrane depolarization coupled with the firing discharge of the postsynaptic neuron (Calabresi et al., 1992b). The possible involvement of voltagedependent sodium channels generating action potential discharge in the induction of LTD has been approached by utilizing QX-314-filled electrodes (50 mM). QX-314 is a lidocaine derivative which blocks voltage-dependent sodium channels without affecting excitatory synaptic potentials (Llinas and Yarom, 1981). After $10 \mathrm{~min}$ of recording intracellular injection of QX314 completely abolished current- and synaptically evoked action potentials in striatal neurons. Under this condition, tetanic stimulation produced only a minor depression of the EPSP amplitude (Fig. 3, solid circles). This result can be explained either by assuming that activation of postsynaptic voltage-dependent sodium channels is required "per se" to induce striatal LTD or by postulating that postsynaptic action potential discharge is simply necessary to reach a membrane depolarization sufficient to activate voltage-dependent $\mathrm{Ca}^{2+}$ channels (Llinas, 1988; Bertolino and Llinas, 1992). To investigate this question, in some QX-314-filled neurons, before the delivery of each train of stimuli, the cell was depolarized at a membrane potential ranging between $-30 \mathrm{mV}$ and $-20 \mathrm{mV}$ by injecting continuous positive current. This depolarizing current was removed after the end of each train. This procedure revealed a synaptic LTD similar to that observed in control neurons even in QX-314-filled neu-

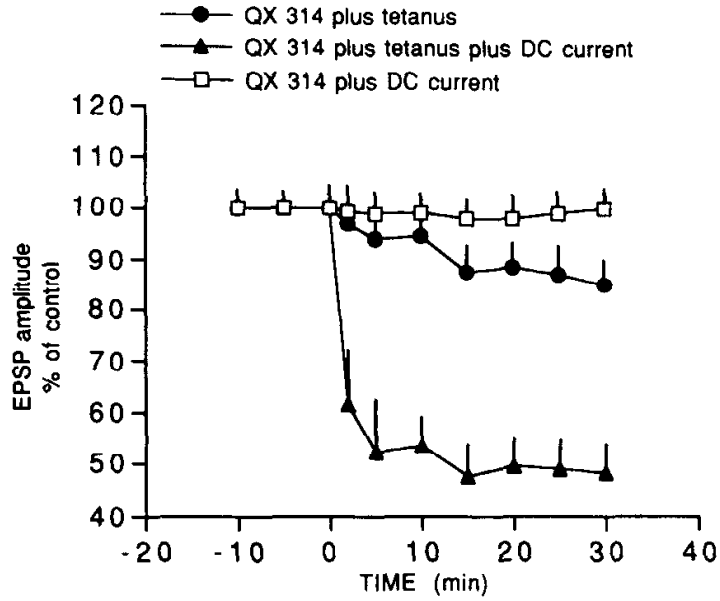

A $\sqrt{--D}$ tetanus

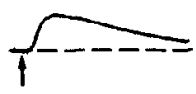

$20 \mathrm{mV} \mid$

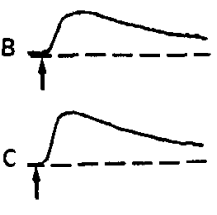

pre

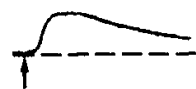

tetanus plus DC current

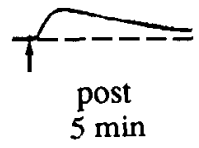

DC current

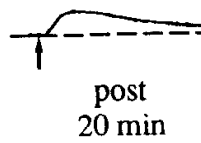

Figure 3. LTD in QX-314-filled neurons. The graph shows that in QX-314-filled neurons tetanic stimulation alone produced only a minor depression of the EPSP amplitude (solid circles, $n=8$ ); when tetanic stimulation was coupled with the injection of positive DC current (see text for details), a significant LTD was observed (solid triangles, $n=4$ ). The injection of DC current in the absence of tetanic stimulation did not induce significant changes of EPSP amplitude (open squares, $n=$ 4). The lower part of the figure shows three experiments obtained from QX-314-filled cells. $A$. Effect of tetanic stimulation in the absence of DC current. $B$, Effect of depolarizing DC current in the absence of tetanic stimulation. $C$. Effect of tetanic stimulation coupled with depolarizing DC current. The RMP was $-85 \mathrm{mV}$ in all the three experiments.

rons (Fig. 3, solid triangles). Under this condition the statistical analysis (paired $t$ test) showed a significant $(p<0.001)$ depression of the control EPSP $20 \mathrm{~min}$ after tetanic stimulation. Injection of continuous current in the absence of tetanic stimulation did not cause any permanent change of the corticostriatal synaptic transmission (Fig. 3, open squares). This evidence indicates that discharge of sodium-mediated action potentials during the tetanus is functionally important mainly because it causes a secondary activation of voltage-dependent $\mathrm{Ca}^{2+}$ channels. The rise of intracellular $\mathrm{Ca}^{2}+$ concentration may trigger the events leading to striatal LTD.

\section{Effect of nifedipine on striatal LTD}

The evidence that in QX-314-filled neurons striatal LTD could be restored by coupling tetanic stimulation with membrane depolarization of the postsynaptic neuron lead us to study the role of high-voltage-activated (HVA) $\mathrm{Ca}^{2+}$ channels in the generation of striatal LTD. Nifedipine $(10 \mu \mathrm{M})$, a dihydropyridine (DHP) antagonist of L-type $\mathrm{HVA} \mathrm{Ca}^{2+}$ channels, did not significantly affect EPSP amplitude in most of the recorded neurons ( 8 out of 10 cells, $p>0.05$; Fig. 4 , Table 1 ). Only in two neurons 
this $\mathrm{Ca}^{2+}$ antagonist produced a small reduction of EPSP amplitude (respectively, $-10 \%$ and $-15 \%$ ). Nifedipine also failed to alter the resting membrane potential and current-voltage curves recorded in either current-clamp or voltage-clamp mode (Fig. 4). Firing discharge evoked by intracellular injection of positive current was not affected by nifedipine (Fig. 4). Incubation of the slice in $10 \mu \mathrm{M}$ nifedipine $(10 \mathrm{~min})$ prevented the generation of posttetanic LTD both in extracellular $(n=5)$ and intracellular experiments $(n=10)$ (Fig. 5). In the extracellular experiments, a paired $t$ test showed no significant change of the control field potential amplitude in comparison with the amplitude of the potential recorded $20 \mathrm{~min}$ after tetanic stimulation. In these cxperiments only a small posttetanic potentiation declining within 10-15 min was observed. In intracellular experiments this small potentiation persisted throughout the recording period. The statistical analysis, performed 20 min after tetanic stimulation, showed that this increase of the EPSP amplitude was slight, but significant $(p<0.05)$.

As previously reported for ventral striatal (Horne and Kemp, 1991) and neostriatal (Swart $\angle$ et al., 1993) cells, 0.3-5 $\mu \mathrm{M} \omega$-conotoxin, an antagonist of $\mathrm{N}$-type $\mathrm{Ca}^{2+}$ channels, produced by itself a significant reduction of EPSP amplitude (Table 1). Since this potent presynaptic action of conotoxin would not allow an unequivocal interpretation of its possible effects on synaptic plasticity, this $\mathrm{Ca}^{2+}$ channel antagonist was not studied on posttetanic LTD.

\section{Blockade of LTD by $\mathrm{H}-7$, staurosporine, and calphostin $\mathrm{C}$}

To investigate whether an activation of $\mathrm{Ca}^{2 *}$-dependent protcin kinases is necessary for striatal LTD, we tested the action of $\mathrm{H}-7$, a general protein kinase inhibitor which binds to the catalytic domain (Hidaka and Kobayashi, 1992), on the generation of this form of synaptic plasticity. As shown in Figure 6, incubation of the slices in 10-50 $\mathrm{M} \mathrm{H-7} \mathrm{(the} \mathrm{period} \mathrm{of} \mathrm{incubation}$ in these experiments and in the following ones started $15 \mathrm{~min}$ before the tetanus) reduced in a dose-dependent manner the striatal LTD in both extracellular and intracellular recordings. Under this condition the statistical analysis showed no significant change of control field potential amplitude $20 \mathrm{~min}$ after tetanic stimulation. Intracellular experiments showed that in the presence of $10 \mu \mathrm{M} \mathrm{H}-7$ there was a slight, but significant ( $p$ $<0.05$ ) posttetanic depression. In the presence of $50 \mu \mathrm{M} \mathrm{H}-7$ no significant posttetanic depression was observed. We also studied the effect of staurosporine, which binds to the regulatory domain of the protein kinase C (PKC) (Hidaka and Kobayashi, 1992; Nishizuka, 1992), on the generation of striatal LTD. Also the incubation of the slices in staurosporine (10-50 nM) inhibited the development of posttetanic LTD in a dose-dependent manner (Fig. 7). In the presence of $10 \mathrm{~nm}$ staurosporine only a small, but significant $(p<0.05)$ depression of EPSP amplitude was measured $20 \mathrm{~min}$ after tetanic stimulation while in the presence of $50 \mathrm{~nm}$ staurosporine the EPSP did not show any significant posttetanic change. Since both $\mathrm{H}-7$ and staurosporine are nonselective PKC inhibitors, we also tested the action of calphostin C, a more specific nonpeptide, membrane-permeable PKC inhibitor (Kobayashi et al., 1989; Linden and Connor, 1991), on striatal LTD. Incubation of the slices in $1 \mu \mathrm{M}$ calphostin C blocked the posttetanic LTD both in extracellular and intracellular experiments (Fig. 8). In fact, under this condition, the comparison of the control EPSP with the potential measured 20 min after tetanic stimulation did not reveal significant posttetanic changes.
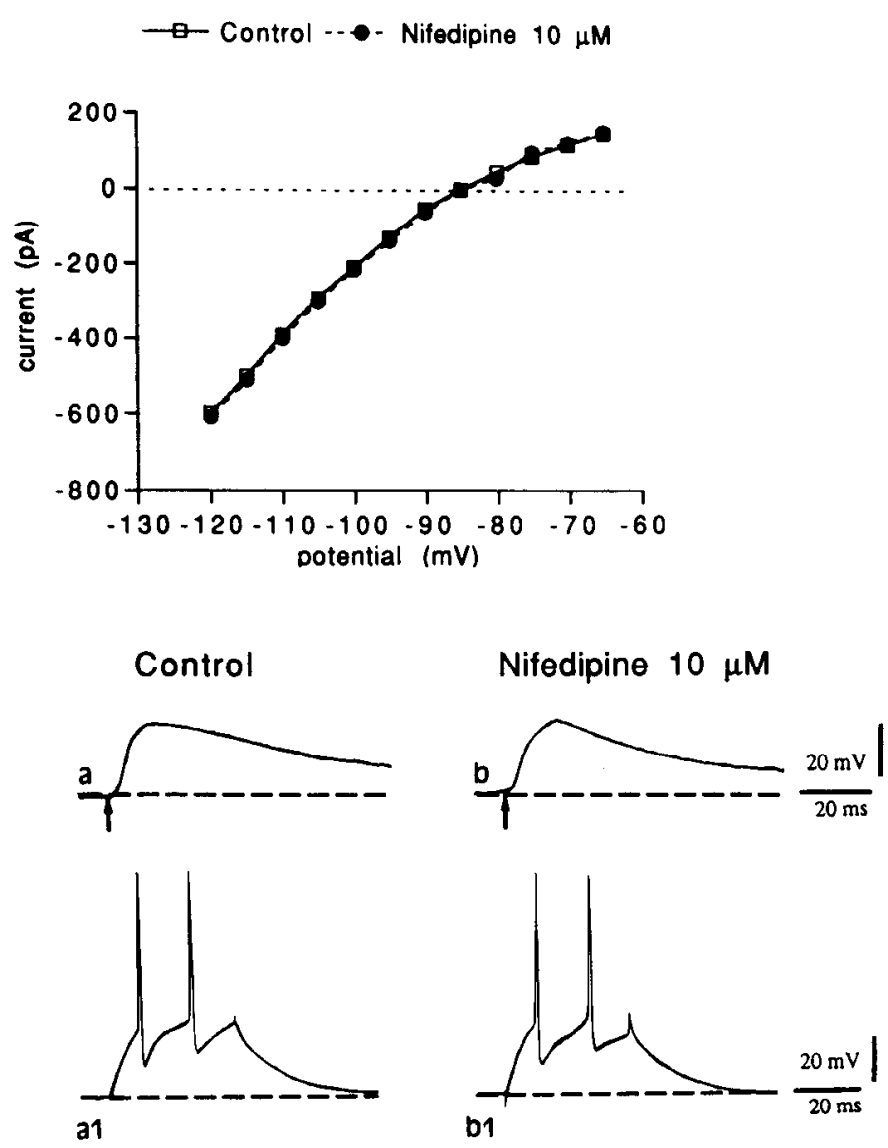

Figure 4. Nifedipine by itself does not affect current-voltage relationship, EPSP amplitude, and current-evoked firing discharge of striatal neurons. The graph in the upper part of the figure shows the currentvoltage relationship obtained from a neuron before (open squares) and during (solid circles) incubation $(10 \mathrm{~min}$ ) in $10 \mu \mathrm{m}$ nifedipine. The plots were obtained from a single microelectrode voltage clamp experiment by holding the cell at $-85 \mathrm{mV}$ and applying positive and negative voltage steps (0.5-3 sec duration; see Calabresi et al., 1993). In the lower part of the figure the traces in the upper row represent EPSPs recorded, respectively, before $(a)$ and during $(b, 10 \mathrm{~min})$ bath application of 10 $\mu \mathrm{M}$ nifedipine. In the lower row current-evoked (1 nA positive current) firing discharge is shown before (al) and during (bl, $10 \mathrm{~min})$ bath application of $10 \mu \mathrm{M}$ nifedipine. Traces shown in $a, b$ and $a l, b l$ were recorded from the same neuron $(\mathrm{RMP}=-86 \mathrm{mV}$ ).

The slightly different time courses of the LTD inhibition by protein kinases inhibitors as dctcctcd by extracellular and intracellular experiments can be attributed to the heterogeneity of the cell population generating the field potential in comparison to the more homogeneous class of neurons (presumably medium spiny cells) recorded during the intracellular experiments.

H-7, staurosporine and calphostin C did not produce by themselves significant changes of EPSP amplitude and of intrinsic membrane properties (membrane potential and $I-V$ curves) of the recorded neurons (Fig. 9, Table 1). H-7, staurosporine, and calphostin $C$, as well as nifedipine and intracellularly applied $\mathrm{Ca}^{2+}$ chelators, did not affect the amplitude of the membrane depolarizations caused by tetanic stimulation (Table 1).

\section{Discussion}

Role of $\mathrm{Ca}^{2+}$ ions in striatal LTD

The blockade of striatal LTD by intracellular injection of $\mathrm{Ca}^{2+}$ chelators suggests that an increase of free $\mathrm{Ca}^{2+}$ concentration is 
A

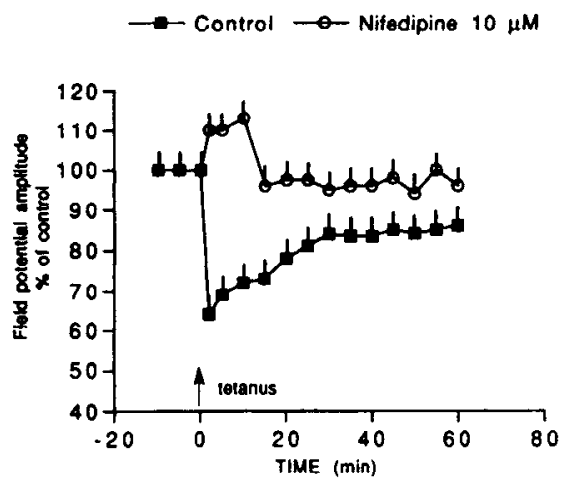

A1

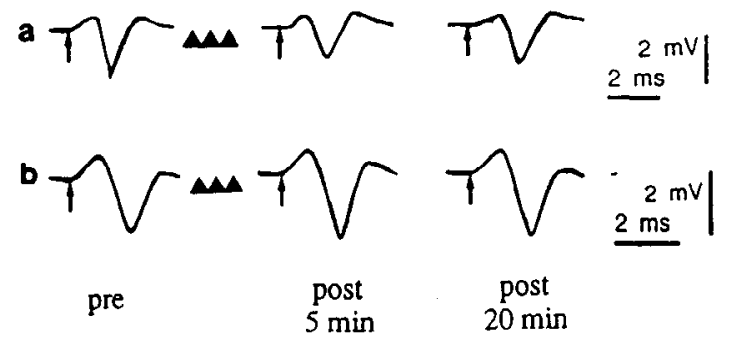

B

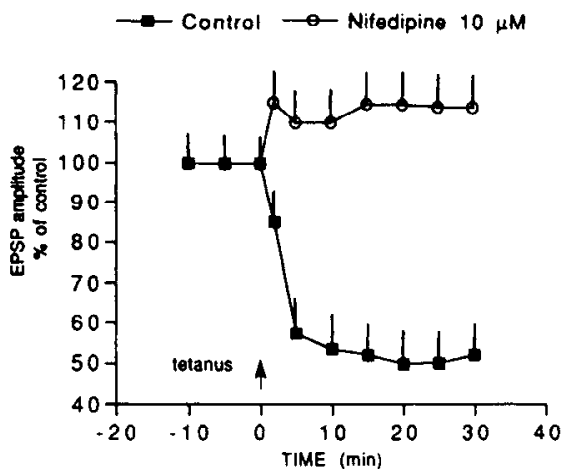

B1

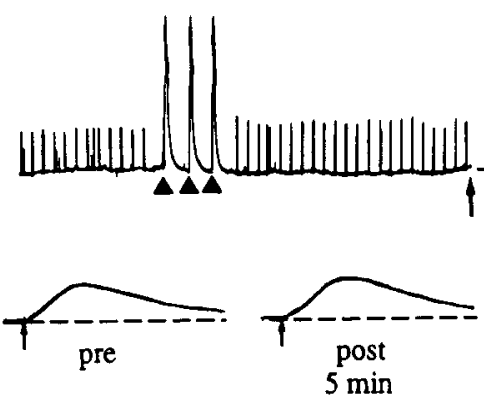

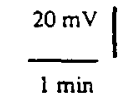

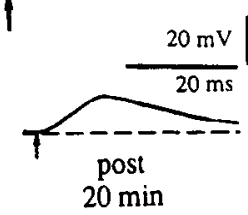

Figure 5. Effects of nifedipine on striatal LTD. A, Tetanic stimulation induced, in control condition, a depression of the amplitude of the extracellularly recorded field potentials ( $n=20$, solid squares). After incubation of the slices in $10 \mu \mathrm{M}$ nifedipine the tetanic stimulation caused a brief posttetanic potentiation of the field potential, followed by the recovery of the field potential amplitude to the initial values ( $n=5$, open circles). A1. The traces shown in the upper row (a) represent field potentials recorded before (pre) and after tetanic stimulation (5 and 20 min) under control condition. The traces shown in the lower row represent field potentials recorded in $10 \mu \mathrm{M}$ nifedipine before (pre) and after tetanic stimulation ( 5 and $20 \mathrm{~min}$ ). Note the generation of LTD in control condition, but not in the presence of this $\mathrm{Ca}^{2+}$ channel antagonist. $B$, The graph shows the effect of $10 \mu \mathrm{M}$ nifedipine on striatal LTD in intracellularly recorded neurons. In control condition tetanic stimulation induced LTD ( $n=20$, solid squares), while in the presence of $10 \mu \mathrm{M}$ nifedipine tetanus caused only a slight potentiation of the EPSPs amplitude ( $n=10$, open circles). B1, This part of the figure shows a single intracellular experiment in the presence of $10 \mu \mathrm{M}$ nifedipine. Note that under this condition tetanic stimulation failed to induce LTD $(\mathrm{RMP}=-86 \mathrm{mV})$.

necessary for this form of synaptic plasticity. Furthermore, this finding suggests that a rise of the intracellular $\mathrm{Ca}^{2+}$ may be a limiting step for the activation of the metabolic cascade underlying striatal LTD. An open question is the mechanism underlying the increase of intracellular free $\mathrm{Ca}^{2}+$ concentration following tetanic stimulation. The involvement of NMDA-activated $\mathrm{Ca}^{2+}$ channels can be ruled out since striatal LTD, unlike LTP in the CAl region of the hippocampus (Madison et al., 1991), is not affected by NMDA receptor antagonists (Calabresi et al., 1992b). Two alternative hypothesis can be considered: (1) the rise in intracellular $\mathrm{Ca}^{2+}$ is caused by the activation of voltagedependent $\mathrm{Ca}^{2+}$ channels and (2) a $\mathrm{Ca}^{2+}$ mobilization from intracellular stores is involved in the generation of striatal LTD. These two possibilities do not exclude each other and they are both supported by experimental evidences. In QX-314-filled neurons postsynaptic voltage-dependent sodium channels are blocked: in these cells tetanic stimulation of corticostriatal fibers can still induce LTD. However, to generate this phenomenon, the membrane potential has to reach a level of depolarization (up to $-20 \mathrm{mV}$ ) which is very close to the threshold for the activation of voltage-dependent $\mathrm{Ca}^{2+}$ channels in striatal (Hoehn et al., 1993) and other central neurons (Llinas, 1988). This evidence suggests the involvement of voltage-dependent $\mathrm{Ca}^{2+}$ channels in the generation of striatal LTD. A further finding in favor of an involvement of voltage-dependent $\mathrm{Ca}^{2+}$ channels in striatal LTD is its blockade by the L-type $\mathrm{Ca}^{2+}$ channel antag- onist nifedipine. It is interesting to note that in the striatum, as well as in other brain areas (Horne and Kemp, 1991; Pfrieger et al., 1992), L-type $\mathrm{Ca}^{2}{ }^{+}$channels do not seem to play a major role in the presynaptic control of glutamate-mediated synaptic potentials. Nevertheless. DHP-sensitive channels are responsible for at least part of the somatic $\mathrm{HVA} \mathrm{Ca}^{2}+$ currents measured in striatal neurons after potassium channel blockade (Hoehn et al., 1993). In hippocampal neurons clustering of L-type $\mathrm{Ca}^{2+}$ channels has been shown at the dendritic region and it has been suggested that these channels may operate in this area to integrate synaptic inputs (Westenbroek et al., 1990). We have shown that these $\mathrm{HVA} \mathrm{Ca}^{2}+$ channels may contribute to the formation of striatal synaptic plasticity caused by tetanic stimulation of the corticostriatal pathway. Wc would like to suggest a postsynaptic dendritic location of the DHP-sensitive channels involved in striatal LTD; however, our data (obtained by bath application of nifedipine) do not allow any definitive conclusion on the location of these channels.

As it has been reported for other forms of synaptic plasticity (Harvey and Collingridge, 1992; Kato, 1993), mobilization of $\mathrm{Ca}^{2}+$ ions from intracellular stores may also be an important factor for striatal LTD. We have recently shown that both lithium (Calabresi et al., 1993) and L-AP3 (Calabresi et al., 1992b), an antagonist of glutamate metabotropic receptors, block striatal LTD. Lithium and AP3 are known to alter $\mathrm{Ca}^{2+}$ mobilization from intracellular stores by affecting PI turnover (Nahorski et 
A

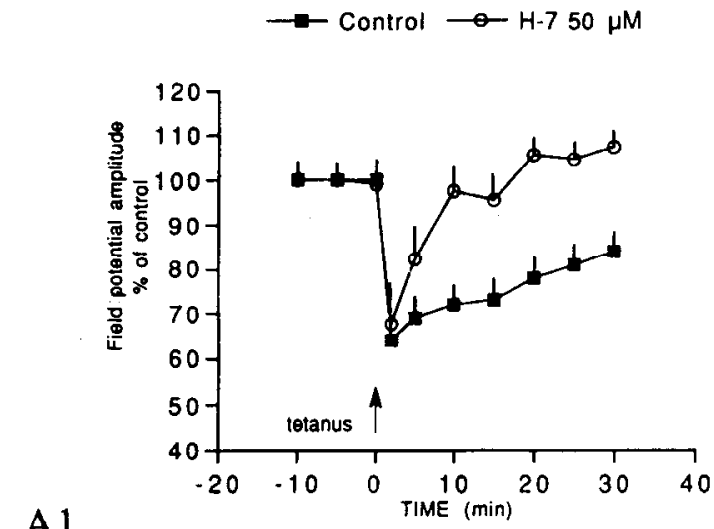

Al

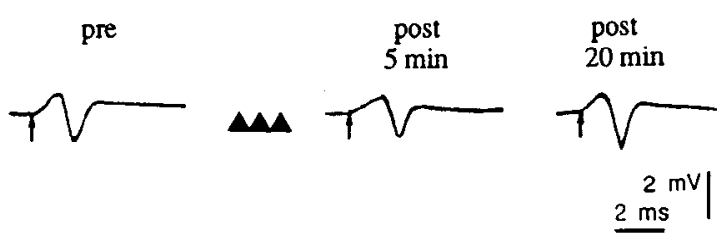

B

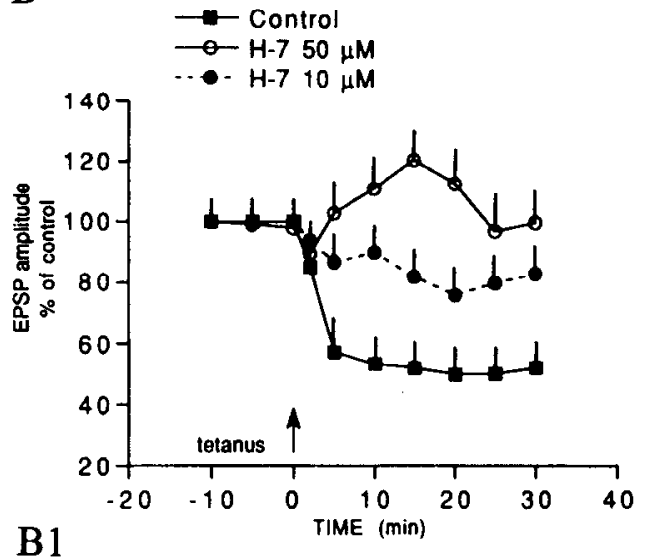

B1

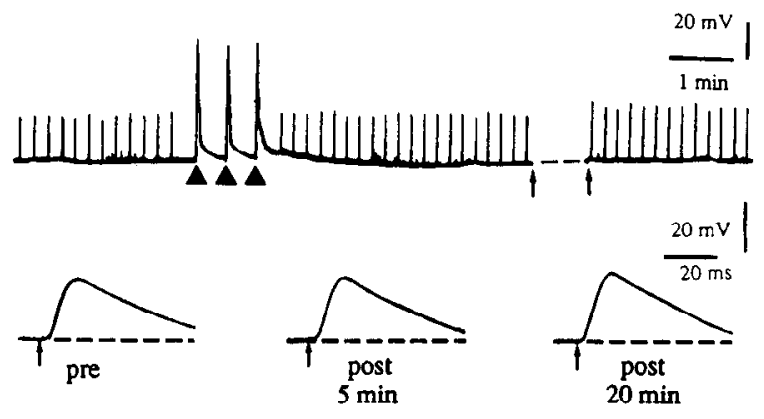

Figure 6. H-7 blocks striatal LTD. A, The graph shows that tetanic stimulation of corticostriatal pathway under control conditions produced LTD of extracellularly recorded field potentials (solid squares, $n=20$ ); in slices incubated in $50 \mu \mathrm{M} \mathrm{H}-7$ tetanic stimulation causcd only a short-term depression of the evoked potentials (open circles, $n=9$ ). $A 1$, This part of the figure shows a single experiment in the presence of $50 \mu \mathrm{M} H-7$ : in this condition tetanic stimulation evoked only a transient decrease of the field potential amplitude. $B$, The graph shows the effect of tetanic stimulation in control condition (solid squares, $n=20)$ and in the presence of two different concentrations of $\mathrm{H}-7(10 \mu \mathrm{M}$, solid circles, $n=4 ; 50$ $\mu \mathrm{M}$, open circles, $n=10$ ). B1, This part of the figure shows a single intracellular experiment in the presence of $50 \mu \mathrm{M} \mathrm{H}-7$. Note that under this condition tetanic stimulation failed to induce LTD (RMP $=-84 \mathrm{mV}$ ).

al., 1991; Nakanishi, 1992; Berridge, 1993): this mechanism is likely to be involved in the blockade of striatal LTD by lithium and L-AP3. Thus, the inhibitory action of these drugs on striatal LTD suggests the possibility that the raise of free $\mathrm{Ca}^{2+}$ concentration generating striatal LTD is caused by the mobilization of this ion from intracellular stores.

\section{Role of $\mathrm{Ca}^{2+}$-dependent protein kinases in striatal LTD}

Given that a rise in $\mathrm{Ca}^{2+}$ is an essential step in the generation of striatal LTD, the following question is: what are the biochemical processes activated by $\mathrm{Ca}^{2+}$ that are responsible for LTD? Here we have shown that $\mathrm{H}-7$, staurosporine and calphostin $\mathrm{C}$ are able to block striatal LTD. Both $\mathrm{H}-7$ (Lovinger et al., 1987; Malinow et al., 1988; Malinow et al., 1989; Leahy and Vallano, 1991; Huang et al., 1992) and staurosporine (Matthies et al., 1991) have been shown to block hippocampal LTP. These effects have been often attributed to an inhibition of PKC. However, $\mathrm{H}-7$ is a general kinase inhibitor and staurosporine can inhibit cAMP-dependent kinase, cGMP-dependent protein kinase, and CaM-Kinase II. Therefore, it is possible that the effects of $\mathrm{H}-7$ and staurosporine on striatal LTD may involve $\mathrm{Ca}^{2+}$-dependent protein kinases other than PKC. Calphostin $\mathrm{C}$ has been proposed as a more selective inhibitor of PKC (Kobayashi et al., 1989). Since micromolar concentrations of calphostin C block cerebellar LTD, it has been postulated that $\mathrm{PKC}$ is required for this form of synaptic plasticity (Linden and
Connor, 1991). Our data show that similar concentrations of this inhibitor were able to block striatal LTD suggesting a possible role of PKC also in this form of synaptic plasticity. However, we cannot exclude that even this inhibitor may alter different kinases.

In most of our experiments we used bath application of pharmacological agents. This experimental approach does not exclude that at least part of the effects observed may be attributed to presynaptic sites of actions and may involve changes in transmitter release. Changes in the presynaptic release of excitatory amino acids have been involved in hippocampal LTP (for reviews, see Kuba and Kumamoto, 1990; Madison et al., 1991). Our experiments utilizing intracellular application of $\mathrm{Ca}^{2+}$ chelators indicate the involvement of postsynaptic mechanisms in striatal LTD. However, it is also possible that, as suggested by Garcia-Munoz et al. (1992), long-term changes in transmitter release from corticostriatal terminals may play an important role in this form of synaptic plasticity.

\section{Comparison with other forms of synaptic plasticity}

Since the discovery of LTP in the hippocampus (Bliss and Lomo, 1973), use-dependent enhancement of synaptic transmission has been observed in a large number of structures. More recently, evidence has been obtained that synaptic transmission can also undergo LTD. The stimulation protocols used for the induction of LTD differ in different structures of the CNS. In the neocortex 
A

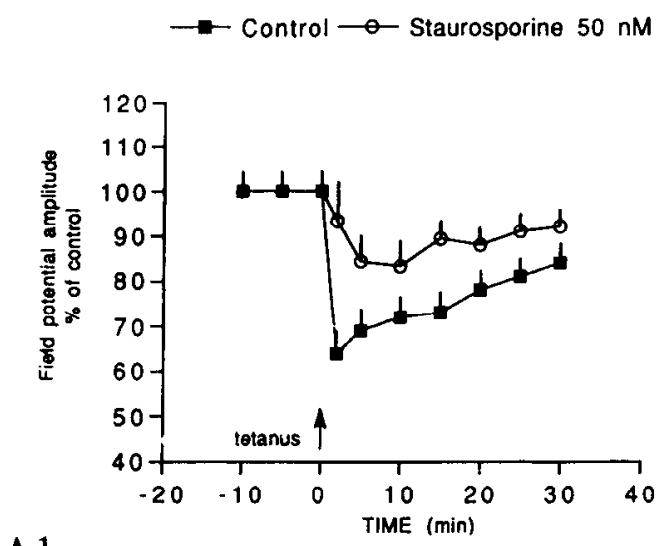

A1

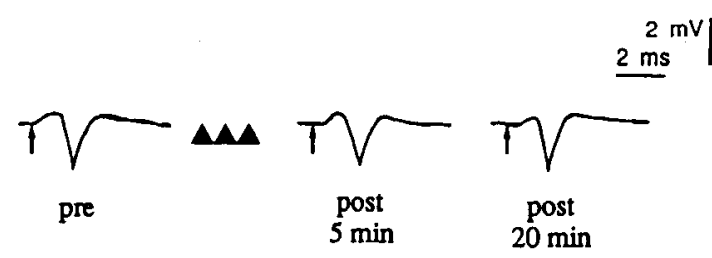

B

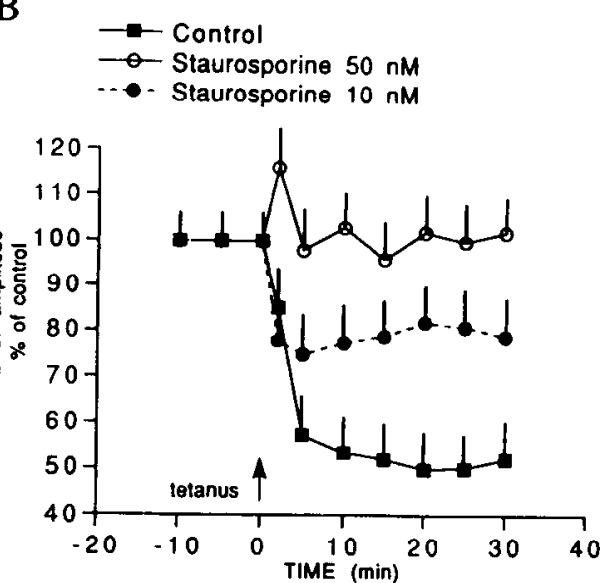

$\mathrm{B} 1$

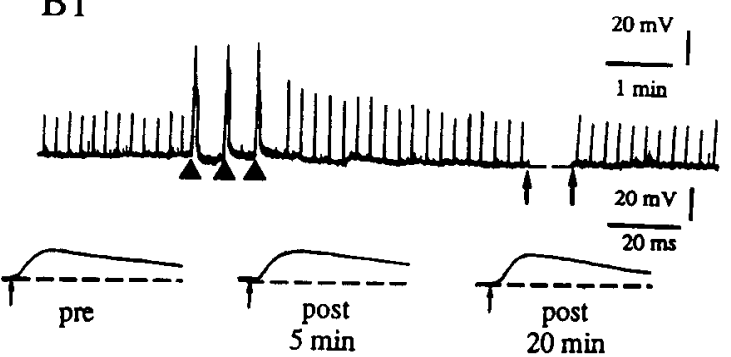

Figure 7. Staurosporine blocks striatal LTD. A. The graph shows that in control condition tetanic stimulation evoked LTD of field potential amplitude (filled squares, $n=20$ ); in the presence of $50 \mathrm{~nm}$ staurosporine the tetanus produced only a minor depression of the evoked potentials (open circles, $n=9$ ). Al, This part of the figure shows a single extracellular experiment in the presence of 50 nM staurosporine: in the presence of this kinase inhibitor only a transient posttetanic depression was observed. $B$, The graph shows the effect of tetanic stimulation of EPSP amplitude in control condition (solid squares, $n=20)$ and in the presence of different concentrations of staurosporine ( $10 \mathrm{nM}$, solid circles, $n=4 ; 50 \mathrm{nM}$, open circles, $n=9$ ). Note that staurosporine causes a dose-dependent inhibition of striatal LTD. Bl, This part of the figure shows a single intracellular experiment performed in the presence of $50 \mathrm{nM}$ staurosporine: under this condition tetanic stimulation failed to induce striatal LTD $(\mathrm{RMP}=-86$ $\mathrm{mV})$.

(Hirsch and Crepcl, 1990; Artola and Singer, 1993) and the striatum (Calabresi et al., 1992; Lovinger et al., 1993; Walsh, 1993) LTD can be induced by high frequency tetanic stimuli that resemble those suitable for the induction of LTP in the hippocampus. By contrast, in CAl region of the hippocampus (Dudek and Bear, 1992; Mulkey and Malenka, 1992) low-frequency stimulation $(1-15 \mathrm{~Hz})$ is more effective in inducing LTD, especially if maintained over prolonged periods of time. In the cerebellum LTD is obtained only if different inputs are activated in conjunction. In fact, coactivation of parallel fibers and climbing fibers causes LTD of synaptic transmission between parallel fibers and Purkinje neurons (Ito et al., 1982). As it has been recently stressed (Artola and Singer, 1993), despite the fact that the stimulation protocols for LTD generation differ in various brain structures, the induction mechanisms share common features. Generation of LTD requires depolarization of the postsynaptic neurons. In fact, cerebellar (Hirano, 1990; Crepel and Jaillard, 1991), cortical (Artola et al., 1990), hippocampal (Mulkey and Malenka. 1992), and striatal (Calabresi et al., 1992b) LTDs are blocked when the postsynaptic cell is hyperpolarized during the conditioning stimulation. Another common characteristic of the LTDs studied in different brain areas is their dependency on intracellular $\mathrm{Ca}^{2}+$ concentration in the postsynaptic cell. Intracellular injection of $\mathrm{Ca}^{2}+$ chelators blocks LTD in the cerebellum (Sakurai, 1990), neocortex (Brocher et al., 1992), hippocampus (Mulkey and Malenka, 1992), and striatum (present study). Interestingly, intracellular $\mathrm{Ca}^{2+}$ concentration influences also the cxpression of LTP in different brain areas (for reviews, see Kuba and Kumamoto, 1990; Madison et al., 1991; Artola and Singer. 1993). It has been recently postulated that a stronger depolarization and a greater increase in intracellular $\mathrm{Ca}^{2+}$ concentration are required to induce LTP than to initiate LTD (Artola and Singer, 1993). Another explanation for dependency on the intracellular $\mathrm{Ca}^{2}{ }^{+}$concentration of both LTD and LTP is the possible different spatial distribution of $\mathrm{Ca}^{2+}$ changes in the postsynaptic cell during the generation of synaptic plasticity (Koch and Zador, 1993). These possibilities require investigation by $\mathrm{Ca}^{2+}$ imaging techniques.

Since a high frequency of stimulation is required for the induction of striatal LTD, an issue that needs to be addressed for the physiological relevance of this form of synaptic plasticity concerns the electrical properties and the firing pattern of corticostriatal neurons. Recently, Cowan and Wilson (1994) have shown that identificd corticostriatal ncurons intracellularly recorded in vivo possess spontaneous burst firing pattern: during spontaneous membrane fluctuations these cells can fire action potentials at very high frequency. This finding is in good agreement with the characteristics of the synaptic stimulation necessary to induce LTD in the striatum.

\section{Functional aspects}

We have shown that repetitive activation of corticostriatal fibers produces LTD of excitatory synaptic transmission in striatal neurons. The great majority of these neurons are small GA- 


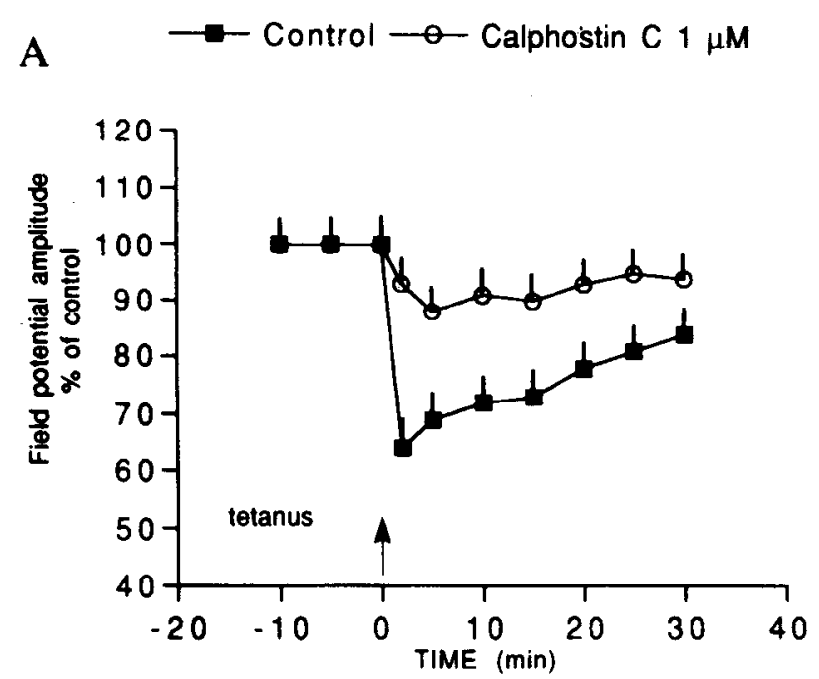

B

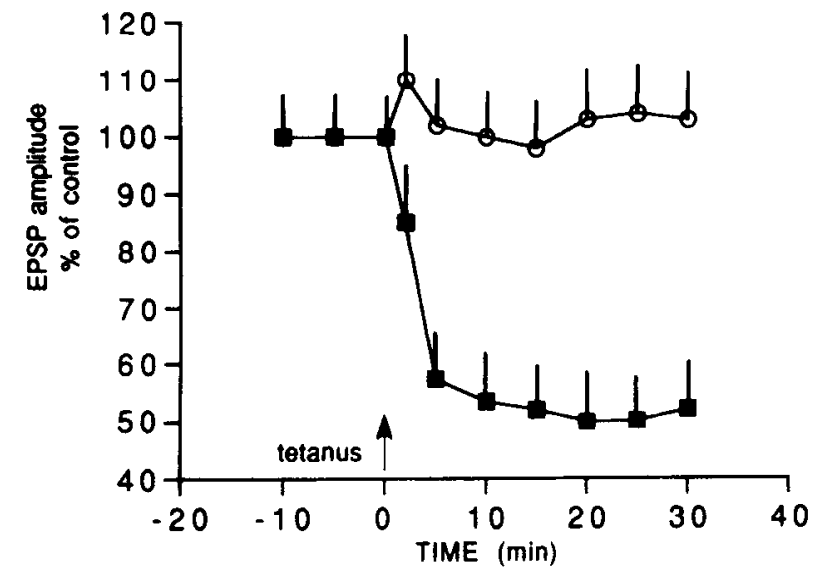

Figure 8. Calphostin C blocks striatal LTD. $A$, The graph shows that tetanic stimulation induced LTD of the evoked field potentials in control condition (solid squares, $n=20$ ). In the presence of $1 \mu \mathrm{M}$ calphostin C (open circles, $n=4$ ) the tetanus produced only a small depression of the extracellularly recorded potentials. $B$, The graph shows the effect of repetitive stimulation on the EPSP amplitude in control condition (solid squares, $n=20$ ) and in the presence of $1 \mu \mathrm{M}$ calphostin $\mathrm{C}$ (open circles, $n=4$ ). Note that in the presence of calphostin C striatal LTD was blocked.

BAergic cells projecting to different structures of the basal ganglia (globus pallidus and substantia nigra) (for reviews, see Groves, 1983; Graybiel, 1990). A long-term reduction of the electrical activity of these GABAergic neurons will cause a decreased inhibitory influence on the output structures of the basal ganglia. This disinhibitory mechanism within the basal ganglia may represent the neuronal substrate for motor activation and for the storage of motor skills (De Long, 1990; Seitz, 1990; Hikosaka, 1991). Such a mechanism requires the participation of different receptors and several metabolic events: activation of AMPA-like and metabotropic glutamate receptors, coactivation of D1 and D2 dopamine receptors, rise in intracellular $\mathrm{Ca}^{2+}$ concentration, and stimulation of $\mathrm{Ca}^{2+}$-dependent kinases. It is possible that different drugs alter striatal LTD by influencing this cascade of physiological and biochemical events. These changes may ultimately affect motor behavior.
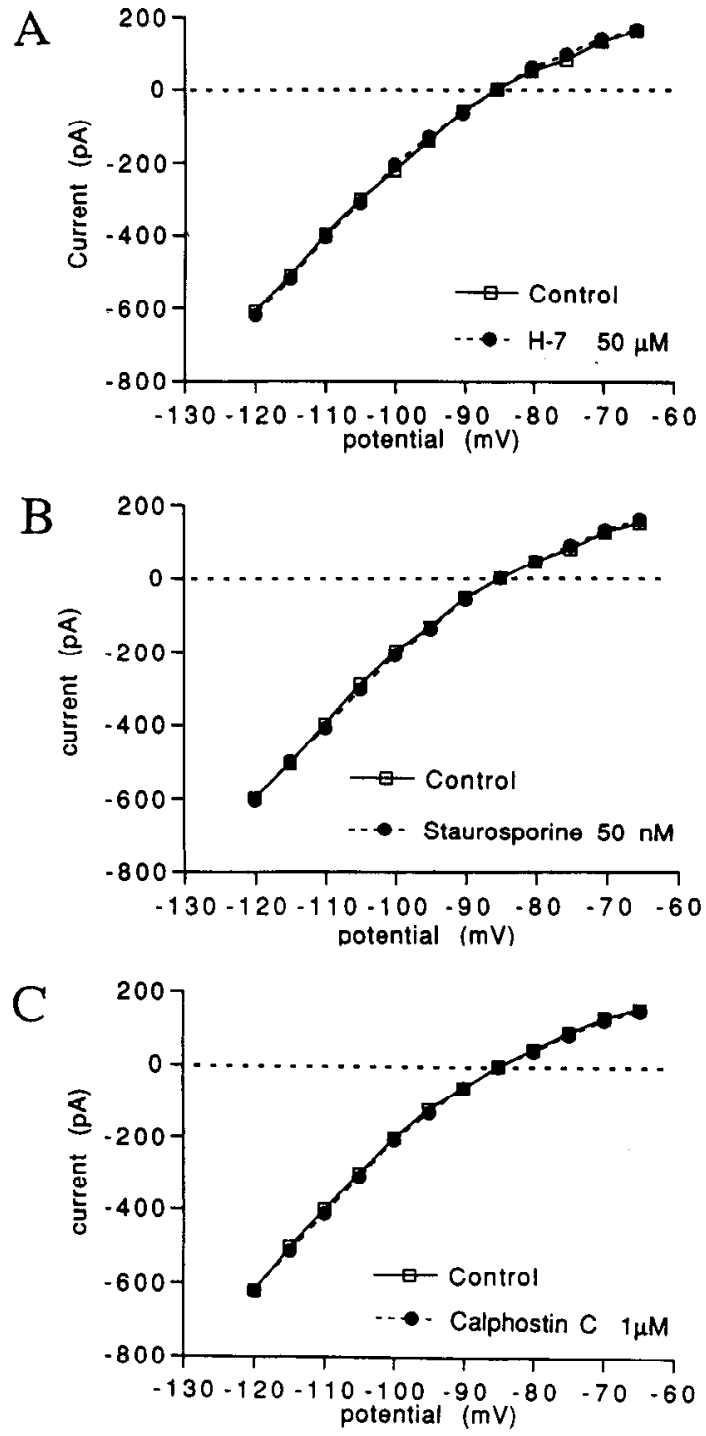

Figure 9. H-7, staurosporine, and calphostin $C$ do not alter currentvoltage relationship of striatal neurons. The plots in $A-C$ show, respectively, the lack of effect of $\mathrm{H}-7$, staurosporine, and calphostin $\mathrm{C}$ on the current-voltage relationship of three striatal cells. The plots were obtained from voltage-clamp experiments by holding the cells at $-85 \mathrm{mV}$ and applying positive and negative steps $(0.5-3 \mathrm{sec})$.

\section{References}

Alger BE, Teyler TJ (1976) Long-term and short-term plasticity in the CA1, CA 3 and dentate regions of the hippocampal slice. Brain Res 110:463-480.

Artola A, Singer W (1987) Long-term potentiation and NMDA receptors in rat visual cortex. Nature 330:649-652.

Artola A, Singer W (1993) Long-term depression of excitatory synaptic transmission and its relationship to long-term potentiation. Trends Neurosci 16:480-487.

Artola A, Brocher S, Singer W (1990) Different voltage-dependent thresholds for inducing long-term depression and long-term potentiation in slices of rat visual cortex. Nature 347:69-72.

Berridge MJ (1993) Inositol trisphosphate and calcium signalling. $\mathrm{Na}-$ ture $361: 315-325$.

Bertolino M, Llinas R (1992) The central role of voltage- activated and receptor-operated calcium channels in neuronal cells. Annu Rev Pharmacol Toxicol 32:399-421.

Bliss TVP, Lomo T (1973) Long-lasting potentiation of synaptic transmission in the dentatc arca of the anacsthetized rabbit following stimulation of the perforant path. J Physiol (Lond) 232:331-356. 
Branchey MH, Charles J, Simpson GM (1976) Extrapyramidal side effects in lithium maintenance therapy. Am J Psychiatry 133:444445 .

Brocher S, Artola A, Singer W (1992) Intracellular injection of $\mathrm{Ca}^{2+}$ chelators blocks induction of long-term depression in rat visual cortex. Proc Natl Acad Sci USA 89:123-127.

Buchwald NA. Price DD, Vernon L, Hull CD (1973) Caudate intracellular response to thalamic and cortical inputs. Exp Neurol 38:311323.

Calabresi P, Mercuri NB, Bernardi G (1990) Synaptic and intrinsic control of membrane excitability of neostriatal neurons. II. An in vitro analysis. J Neurophysiol 63:663-675.

Calabresi P, Mercuri NB, Dc Murtas M, Bernardi G (1991) Involvement of GABA systems in the feed-back regulation of glutamate- and GABA-mediated synaptic potentials in the striatum. J Physiol (Lond) 440:581-599.

Calabresi P, Maj R, Mercuri NB, Bernardi G (1992a) Coactivation of $\mathrm{D} 1$ and D2 dopamine receptors is required for long-term synaptic depression in the striatum. Neurosci Lett 142:95-99.

Calabresi P, Maj R, Pisani A, Mercuri NB, Bernardi G (1992b) Longterm synaptic depression in the striatum: physiological and pharmacological characterization. J Neurosci 12:4224-4233.

Calabresi P. Pisani A. Mercuri NB, Bernardi, G (1992c) Long-term potentiation in the striatum is unmasked by removing the voltagedependent blockade of NMDA receptor channel. Eur J Neurosci 4:929935.

Calabresi P, Pisani A, Mcrcuri NB, Bcrnardi G (1993) Lithium treatment blocks long-term synaptic depression in the striatum. Neuron 10:955-962.

Cherubini E, Herrling PL, Lanfumey L, Stanzione P (1988) Excitatory amino acids in synaptic excitation of rat striatal neurones in vitro. J Physiol (Lond) 400:677-690.

Cowan RL, Wilson CJ (1994) Spontaneous firing patterns and axonal projections of single corticostriatal neurons in the rat medial agranular cortex. J Neurophysiol 71:17-32.

Crepel F, Jaillard D (1991) Pairing of pre- and postsynaptic activities in cerebellar Purkinje cells induces long-term changes in synaptic efficacy in vitro. J Physiol (Lond) 432:123-141

De Long MR (1990) Primate models of movement disorders of basal ganglia origin. Trends Neurosci 13:281-285.

Divac I, Fonnum F, Storm-Mathisen J (1977) High affinity uptake of glutamate in terminals of corticostriatal axons. Nature 266:377-378.

Dudek SM, Bear MF (1992) Homosynaptic long-term depression in area CA1 of the hippocampus and effects of $N$-methyl-D-aspartate receptor blockade. Proc Natl Acad Sci USA 89:4363-4367.

Garcia-Munoz M, Young ST, Groves PM (1992) Presynaptic longterm changes in excitability of the corticostriatal pathway. Neuroreport 3:357-360.

Graybiel AM (1990) Neurotransmitters and neuromodulators in the basal ganglia. Trends Neurosci 13:244-254.

Groves PM (1983) A theory of the functional organization of the neostriatum and the neostriatal control of voluntary movement. Brain Res Rev 5:109-132.

Harvey J, Collingridge GL (1992) Thapsigargin blocks the induction of long-term potentiation in rat hippocampal slices. Neurosci Lett 139:197-200.

Herrling PL (1985) Pharmacology of the corticocaudate excitatory postsynaptic potential in the cat: evidence for its mediation by quisqualate or kainate receptors. Neuroscience 14:417-426.

Hidaka H, Kobayashi R (1992) Pharmacology of protein kinase inhibitors. Annu Rev Pharmacol Toxicol 32:377-397.

Hikosaka O (1991) Basal ganglia-possible role in motor coordination and learning. Curr Opin Neurobiol 1:638-643.

Hirano T (1990) Depression and potentiation of the synaptic transmission between a granule cell and a Purkinje cell in rat cerebellar culture. Neurosci Lett 119:141-144.

Hirsch J, Crepel F (1990) Use-dependent changes in synaptic efficacy in rat prefrontal neurons in vitro. J Physiol (Lond) 432:123-141.

Ioehn K, Watson TWJ, MacVicar BA (1993) Multiple types of calcium channels in acutely isolated rat neostriatal neurons. J Neurosci 13:1244-1257.

Horne AL, Kemp JA (1991) The effecl of cunotoxin GVIA on synaptic transmission within the nucleus accumbens and hippocampus of the rat in vitro. Br J Pharmacol 103:1733-1739.

Huang YY, Colley PA, Routtenberg A (1992) Postsynaptic then pre- synaptic protein kinase $\mathrm{C}$ may be necessary for long-term potentiation. Neuroscience 49:819-827.

Ito M, Sakurai M, Tongroach P (1982) Climbing fibre induced depression of both mossy fiber responsiveness and glutamate sensitivity of cerebellar Purkinje cells. J Physiol (Lond) 324:113-134.

Izquierdo I (1992). Dopamine receptors in the caudate nucleus and memory processes. Trends Pharmacol Sci 13:7-8.

Jiang ZG, North RA (1991) Membrane properties and synaptic responses of rat striatal neurones in vitro. J Physiol (Lond) 443:533553.

Kato N (1993) Dependence of long-term depression on postsynaptic metabotropic glutamate receptors in visual cortex. Proc Natl Acad Sci USA 90:3650-3654.

Kitai ST, Kocsis JD, Preston RJ, Sugimori M (1976) Monosynaptic inputs to caudate neurons identified by intracellular injection of horseradish peroxidase. Brain Res 109:601-606.

Kobayashi E, Nakano H, Morimoto M, Tamaoki T (1989) Calphostin $\mathrm{C}$ (UCN-1028C), a novel microbial compound, is a highly potent and specific inhibitor of protein kinase C. Biochem Biophys Res Commun 159:548-553.

Koch C. Zador A (1993) The function of dendritic spines: devices subserving biochemical rather than electrical compartmentalization. J Neurosci 13:413-422.

Konnerth A, Dreessen J, Augustine GJ (1992) Brief dendritic calcium signals initiate long-lasting synaptic depression in cerebellar Purkinje cells. Proc Natl Acad Sci USA 89:7051-7055.

Kuba K, Kumamoto E (1990) Long-term potentiations in vertcbratc synapses: a variety of cascades with common subprocesses. Prog Neurobiol 34:197-269.

Leahy JC, Vallano ML (1991) Differential effect of isoquinolinesulfonamide protein kinase inhibitors on CAl responses in hippocampal slices. Neuroscience 44:361-370.

Linden DJ, Connor JA (1991) Participation of postsynaptic PKC in cerebellar long-term depression in culture. Science 254:1656-1659.

Llinas RR (1988) The intrinsic electrophysiological properties of mammalian neurons: insight into central nervous system function. Science 242:1654-1664.

Llinas R, Yarom Y (1981) Electrophysiology of mammalian inferior olivary neurones in vitro. Different types of voltage-dependent ionic conductances. J Physiol (Lond) 315:549-567.

Lovinger DM (1991) Trans-1-aminocyclopentane-1,3-dicarboxylic acid (t-ACPD) decreases synaptic excitation in rat striatal slices through a presynaptic action. Neurosci Lett 129:17-21.

Lovinger DM, Wong KL, Murakami K. Routtenberg A (1987) Protein kinase $\mathrm{C}$ inhibitors eliminate hippocampal long-term potentiation. Brain Res 436:177-183.

Lovinger DM, Tyler EC, Merritt A (1993) Short- and long-term synaptic depression in rat neostriatum. J Neurophysiol 70:1937-1949.

Lynch G, Baudry M (1984) The biochemistry of memory: a new and specific hypothesis. Science 224:1057-1063.

Lynch G, Larson J, Kelso S, Barrionuevo G, Schotter F (1983) Intracellular injections of EGTA block induction of hippocampal longterm potentiation. Nature 305:719-721.

Madison DW, Malenka, RC, Nicoll RA (1991) Mechanisms underlying long-term potentiation of synaptic transmission. Annu Rev Neurosci 14:379-397.

Malinow R, Madison DV, Tsien RW (1988) Persistent protein kinase activity underlies long-term potentiation (1988). Nature 335:820824.

Malinow R, Schulman H, Tsien RW (1989) Inhibition of postsynaptic PKC or CaMKII blocks induction, but not expression of LTP. Science 245:862-866.

Mulkay RM, Malenka RC (1992) Mechanisms underlying induction of homosynaptic long-term depression in area CAl of the hippocampus. Neuron 9:967-975.

Nahorski SR, Ragan CI, Challis RAJ (1991) Lithium and the phosphoinositide cycle: an example of uncompetitive inhibition and its pharmacological consequences. Trends Pharmacol Sci 12:297-303.

Nakanishi S (1992) Molccular diversity of glutamate receptors and implications for brain function. Science 258:597-603.

Nishizuka Y (1992) Intracellular signalling by hydrolysis of phospholipids and activation of protein kinase C. Science 258:607-614.

Pfrieger FW, Veselovsky NS, Gottmann K, Lux HD (1992) Pharmacological characterization of calcium currents and synaptic transmission between thalamic neurons in vitro. J Neurosci 12:4347-4357. 
Reubi JC, Cuenod M (1979) Glutamate release in vitro from corticostriatal terminal. Brain Res 176:185-188.

Robertson GS, Robertson HA (1986) Synergistic effects of D1 and D2 dopamine agonists on turning behaviour in rats. Brain Res 384:387390.

Robertson GS, Robertson HA (1987) D1 and D2 dopamine agonist synergism: separate sites of action? Trends Pharmacol Sci 8:295-299.

Sacaan AI, Bymaster FP, Schoepp DD (1992) Metabotropic glutamate receptor activation produces extrapyramidal motor system activation that is mediated by striatal dopamine. J Neurochem 59:245-251.

Sakurai M (1990) Calcium is an intracellular mediator of the climbing fiber in the induction of cerebellar long-term depression. Proc Natl Acad Sci USA 87:3383-3385

Seitz RJ, Roland PE, Bohm C, Greitz T, Stone-Elander S (1990) Motor learning in man: a positron emission tomographic study. Neuroreport $1: 17-20$.

Spencer HJ (1976) Antagonism of cortical excitation of striatal neurons by glutamic acid diethyl-ester: evidence for glutamic acid as an excitatory transmitter in the rat striatum. Brain Res 102:91-101.

Svensson A, Carlsson ML, Carlsson A (1992) Interaction between glutamatergic and dopaminergic tone in the nucleus accumbens of mice: evidence for a dual glutamatergic function with respect to psychomotor control. J Neural Transm 88:235-240.
Swartz KJ, Merritt A, Bean BP, Lovinger DM .(1993) Protein kinase $C$ modulates glutamate receptor inhibition of $\mathrm{Ca}^{2+}$ channels and synaptic transmission. Nature 361:165-168.

Teyler TJ, DiScenna P (1984) Long-term potentiation as a candidate mnemonic device. Brain Res Rev 7:15-28.

Tyrer S, Alexander MS, Regan A, Lee L (1980) An extrapyramidal syndrome after lithium therapy. Br J Psychiatry 136:191-194.

Walsh JP (1993) Depression of excitatory synaptic input in rat striatal neurons. Brain Res 608:123-128.

Walsh JP, Hull CD, Levine MS, Buchwald NA (1989) Kynurenic acid antagonizes the excitatory postsynaptic potential elicited in neostriatal neurons in the in vitro slice of the rat. Brain Res 480:290-293.

Westenbroek RE, Ahlijanian MK, Catterall WA (1990) Clustering of L-type $\mathrm{Ca}^{2+}$ channels at the base of major dendrites in hippocampal pyramidal neurons. Nature 347:281-284.

Wilson C (1994) Corticostriatal neurons of the medial agranular cortex of rats. $J$ Neurophysiol, in press.

Zalutsky RA, Nicoll RA (1990) Comparison of two forms of longterm potentiation in single hippocampal neurons. Science 248:16191624. 